\title{
PENGEMBANGAN LEMBAR KERJA SISWA (LKS) BERBASIS INKUIRI TERBIMBING PADA MATERI POKOK LAJU REAKSI UNTUK SISWA KELAS XI IPA SMA
}

\section{DEVELOPMENT OF STUDENT WORKSHEET BASED ON GUIDED INQUIRY IN SUBJECT MATTER OF REACTION RATE FOR STUDENTS OF CLASS XI IPA SENIOR HIGH SCHOOL}

\author{
Lukmanul Hakim.S ${ }^{1}$, Sugiarti ${ }^{2}$, Jusniar ${ }^{3}$ \\ Pendidikan Kimia, Matematika dan Ilmu Pengetahuan Alam \\ 1,2,3 Universitas Negeri Makassar \\ hakimlukmanul238@gmail.com1
}

\begin{abstract}
This research is research and development which aim to arrange and develop student worksheet for Senior High School grade XI based on guided inquiry on KTSP. Subject is students of class XI $I_{P A}$ SMA Negeri 2 Polewali. The development of this student worksheet refers to developmental model of 4-D by Thiagarajan. that included define phase, design phase, and develop phase. Fourth disseminate phase was not done. This student worksheet has already validated by validator and through limited try out, as well as revised many times by developer so that obtaining valid, effective and practical result. This research showed that: in cognitive aspect, the class completeness is $81,25 \%$; students activities in psychomotor and affective aspect showed positive tendency with each percentage for psychomotor is 81,25\% while for affective aspect is $91 \%$; commonly students gave positive responses toward used student worksheet likewise the responses of their chemistry teachers.
\end{abstract}

Keywords: Developmental Model of 4-D, Guided Inquiry, Research and Development, Student Worksheet

\section{Abstrak}

Penelitian ini merupakan penelitian pengembangan (Research and Development) yang bertujuan untuk menyusun dan mengembangkan Lembar Kerja Siswa (LKS) untuk SMA kelas XI yang berbasis inkuiri terbimbing berdasarkan KTSP. Subjek penelitian ini adalah siswa kelas XI IPA 2 SMA Negeri 2 Polewali. Pengembangan LKS ini mengacu pada model pengembangan 4-D dari Thiagarajan, dkk yang meliputi tahap pendefinisian (define), perancangan (design), dan pengembangan (develop). Tahap penyebarluasan (disseminate) tidak dilakukan. LKS ini telah divalidasi oleh validator/ahli dan telah melalui uji coba terbatas, serta telah mengalami revisi berulang kali oleh pengembang sehingga diperoleh hasil yang valid, efektif, dan praktis. Hasil penelitian ini menunjukkan bahwa: pada aspek kognitif, persen ketuntasan kelas sebesar 81,25 \%; aktivitas siswa pada aspek psikomotorik dan afektif menunjukkan kecenderungan positif dengan persentase masing-masing untuk aspek psikomorik sebesar $81,25 \%$, sementara untuk aspek afektif sebesar $91 \%$, umumnya siswa memberikan respon positif terhadap LKS yang digunakan begitupun juga dengan respon guru kimianya.

Kata Kunci: Model Pengembangan 4-D, Inkuiri Terbimbing, Penelitian Pengembangan, LKS

\section{PENDAHULUAN}

Saat ini pendidikan bukan lagi merupakan kewajiban bagi setiap orang, akan tetapi sudah menjadi kebutuhan yang mendasar.
Melalui pendidikan, seseorang dapat hidup sejahtera dan lebih dihargai atau dihormati oleh orang lain. Oleh karena itu, pemerintah sangat menekankan kepada seluruh rakyat 
Indonesia untuk mengenyam pendidikan setinggi mungkin, hingga sekarang ini pemerintah menerapkan pendidikan wajib belajar 12 tahun demi menekan angka siswa putus sekolah yang sebagian besar dikarenakan faktor ekonomi.

Salah satu kelemahan yang dihadapi dunia pendidikan kita adalah masalah lemahnya proses pembelajaran. Dalam proses pembelajaran, siswa kurang didorong untuk mengembangkan kemampuan berpikir. Proses pembelajaran di dalam kelas diarahkan kepada kemampuan siswa untuk menghafal informasi, otak siswa dipaksa mengingat dan menimbun berbagai informasi tanpa dituntut untuk memahami informasi yang diingatnya itu untuk menghubungkannya dengan kehidupan sehari-hari. Akibatnya ketika siswa kita lulus dari sekolah, mereka pintar secara teoritis, tetapi mereka miskin aplikasi [1].

Sebagian besar siswa menganggap kimia merupakan salah satu mata pelajaran yang sulit di sekolah, sehingga siswa kurang termotivasi untuk belajar kimia. Pembelajaran yang dilakukan oleh guru masih bersifat teacher centrered. Nilai yang diperoleh siswa kurang maksimal, hal ini dikarenakan kemampuan berpikir siswa kurang dimaksimalkan dan pembelajaran yang dilakukan kurang menarik [2].

Peranan guru sebagai motivator sangat penting dalam rangka meningkatkan kegairahan dan pengembangan kegiatan belajar siswa. Guru harus dapat merangsang dan memberikan dorongan serta reinforcement untuk mendinamisasikan potensi siswa, menumbuhkan aktivitas dan kreativitas sehingga terjadi dinamika di dalam proses pembelajaran [3]

Guru sebagai pembelajar pastinya memerlukan alat bantu mengajar dalam menerapkan strategi pembelajaran inkuiri yang dirancangnya. Alat bantu yang digunakan tersebut yang dikenal dengan istilah media yang dapat membantu dalam menyampaikan pesan tertentu kepada siswa sesuai yang diinginkan, agar pesan yang disampaikan itu efektif maka media yang digunakan perlu dirancang sedemikian rupa agar mampu menarik perhatian siswa dan merangsang minat siswa untuk belajar. Menurut Ref. [4] media pembelajaran dapat merupakan wahana penyalur pesan dan informasi belajar. Media pembelajaran yang dirancang secara baik akan sangat membantu siswa dalam mencerna dan memahami materi pelajaran.

Pesan atau informasi yang ingin disampaikan dapat berupa materi pelajaran. Materi pelajaran kimia merupakan materi pembelajaran yang mengandung konsepkonsep dan perhitungan matematik terhadap berbagai kejadian atau fenomena alam yang biasa atau sering terjadi.

Materi kimia mencoba menjelaskan mengapa kejadian atau fenomena itu terjadi secara terperinci, sitematis serta didasarkan pada fakta atau berbagai macam penemuan yang logis. Untuk memahami materi-materi tersebut, diperlukan suatu strategi pembelajaran yang efektif agar siswa dapat mencapai tujuan pembelajaran yang ditentukan. Salah satu media pembelajaran yang dapat digunakan untuk menyampaikan materi kimia adalah Lembar Kerja Siswa (LKS).

Lembar Kerja Siswa adalah lembaranlembaran berisi tugas yang harus dikerjakan oleh siswa. Lembar kerja umumnya berupa petunjuk mengenai langkah-langkah untuk menyelesaikan suatu tugas. Suatu tugas yang diperintahkan dalam lembar kerja harus jelas kompetensi dasar yang akan dicapainya. Tugas-tugas sebuah lembar kerja tidak akan dapat dikerjakan oleh siswa secara baik apabila tidak dilengkapi dengan buku lain atau referensi lain yang terkait dengan materi tugasnya [5]. LKS perlu dirancang berbasis inkuiri terbimbing agar dapat meningkatkan motivasi belajar dan kemampuan berpikir siswa.

Menurut Suyanti menyatakan langkahlangkah dalam pembelajaran inkuiri terbimbing meliputi orientasi, merumusan masalah, menyusun hipotesis, mengumpulkan 
data, menguji hipotesis, dan merumuskan kesimpulan. Langkah ini dapat diterapkan pada media atau bahan ajar seperti LKS yang telah dirancang dengan baik, hal ini dilakukan agar materi yang disampaikan melalui perantara media/bahan ajar dapat membangkitkan rasa ingin tahu siswa dan mengoptimalkan kemampuan siswa [6].

Pengetahuan dan keterampilan yang diperoleh siswa bukan hasil mengingat sejumlah fakta, melainkan seharusnya merupakan hasil dari proses menemukan sendiri, melalui langkah-langkah, yaitu: (a) merumuskan masalah; (b) mengajukan hipotesis; (c) mengumpulkan data melalui observasi; (d) menganalisis dan menyajikan data hasil analisis; dan (e) menyimpulkan dan mengkomunikasikan [7].

Menurut Wulandari, dkk pembelajaran praktikum berbasis inkuiri terbimbing dapat menarik minat serta motivasi belajar siswa. Siswa dapat lebih memahami konsep laju reaksi melalui masalah yang berkaitan dengan pengalaman dan kehidupan seharihari sehingga dapat lebih bermakna bagi siswa [8].

Berdasarkan penelitian yang dilakukan oleh Imaniarta, dkk menujukkan bahwa berdasarkan hasil validasi isi, uji keterbacaan, dan uji keterlaksanaan menyimpulkan bahwa buku petunjuk praktikum kimia SMA berbasis inkuiri terbimbing yang dikembangkan dengan mengacu pada model pembelajaran four-D sudah layak digunakan [9]. Hal ini selaras dengan penelitian yang dilakukan oleh Mawantia, dkk bahwa berdasarkan penilaian validator, modul berbasis inkuri terbimbing hasil pengembangkan melalui model 4-D sangat layak digunakan sebagai sumber belajar di SMK, sementara berdasarkan hasil uji keterbacaan pada siswa diperoleh bahwa modul tersebut layak digunakan [10].

LKS yang sudah jadi dari penerbit yang merupakan salah satu sumber belajar yang digunakan siswa terbilang masih kurang memotivasi siswa belajar. Hal ini dianggap salah satu penyebab hasil belajar siswa pada mata pelajaran kimia khususnya materi laju reaksi cenderung rendah dan masih cukup jauh dari yang diharapkan dengan rata-rata persen ketuntasan kelas sebesar $49 \%$ pada tes hasil belajar materi laju reaksi dengan KKM $=80$ berdasarkan hasil wawancara terhadap guru kimia SMAN 2 Polewali. Tujuan dari penelitian ini yaitu untuk mengembangkan dan mengetahui kelayakan Lembar Kerja Siswa (LKS) berbasis inkuiri terbimbing pada materi pokok laju reaksi untuk siswa kelas XI IPA SMA.

\section{METODE PENELITIAN}

Jenis penelitian yang dilakukan adalah penelitian dan pengembangan (R\&D). Model pengembangan yang digunakan adalah model pengembangan 4-D dari Thiagarajan, dkk. yang meliputi tahap pendefinisian (define), perancangan (design), pengembangan (develop) dan penyebarluasan (disseminate) [11]. Tahapan penyebarluasan tidak dilakukan. Subjek pada penelitian ini adalah siswa SMA Kelas XI IPA 2 dengan jumlah siswa 32 orang. Untuk menilai kelayakan dari LKS yang dikembangkan digunakan kriteria kevalidan, keektifan dan kepraktisan.

Instrumen penelitian yang digunakan untuk mengukur kevalidan LKS adalah lembar validasi yang menggunakan skala Likert yang terdiri dari 4 kategori alternatif pilihan. Keempat kategori alternatif pilihan tersebut adalah angka 4 artinya sangat baik, angka 3 artinya baik, angka 2 artinya tidak baik, angka 1 artinya sangat tidak baik. Instrumen yang digunakan untuk mengukur keefektifan LKS adalah lembar observasi aktivitas siswa yang berupa penilaian kegiatan siswa yang meliputi aspek psikomotorik dan afektif serta tes hasil belajar digunakan untuk memperoleh informasi tentang aspek kognitif dalam hal ini penguasaan siswa terhadap materi laju reaksi setelah kegiatan pembelajaran dan praktikum berlangsung. Instrumen yang digunakan untuk mengukur kepraktisan penggunaan LKS adalah lembar 
keterlaksanaan, lembar keterbacaan, angket respon siswa dan angket respon guru.

\section{HASIL DAN PEMBAHASAN}

\section{Tahap I Pendefinisian}

Tujuan dari tahap ini untuk menetapkan dan menjabarkan serta membatasi syaratsyarat dan kebutuhan dalam pembelajaran.

\section{a. Analis awal-akhir}

Analisis awal-akhir adalah suatu proses sistematis untuk menganalisis masalah mendasar yang terjadi di lapangan dan untuk menyarankan suatu alternatif strategi pemecahan masalah dengan mempertimbangkan teori belajar, tantangan dan tuntunan masa depan sehingga dapat meningkatkan efisiensi dan efektivitas pembelajaran. Masalah pokok yang dihadapi disini adalah terkait alternatif media/bahan ajar di sekolah yang mampu meningkatkan kemampuan siswa dalam berpikir sistematis, logis, dan kritis, mengoptimalkan kemampuan siswa dan membangkitkan rasa ingin tahu siswa.

Analisis awal-akhir meliputi analisis kurikulum, diperoleh informasi bahwa kurikulum yang digunakan di sekolah tempat penelitian adalah Kurikulum Tingkat Satuan Pendidikan (KTSP); hasil wawancara mengenai masalah ketersediaan LKS, berdasarkan hasil wawancara dengan guru mengenai ketersediaan bahan ajar seperti LKS yang berbasis inkuri terbimbing ditemukan bahwa siswa-siswi di sekolah tersebut sebagian besar menggunakan LKS yang sifatnya verifikatif. LKS yang digunakan siswa ini dianggap kurang mampu meningkatkan hasil belajar siswa, hal ini terbukti dengan masih rendahnya rata-rata nilai siswa khususnya pada materi laju reaksi.

\section{b. Analisis siswa}

Analisis siswa merupakan suatu kegiatan untuk mengidentifikasi karakteristik siswa yang diajar. Hal-hal yang perlu dipertimbangkan untuk mengetahui karakteristik siswa antara lain; kemampuan akademik individu, karakteristik fisik, kemampuan kerja kelompok, motivasi belajar, latar belakang ekonomi dan sosial, pengalaman belajar sebelumnya, dsb.

Berdasarkan hasil analisis siswa diperoleh pertama, siswa kelas XI IPA 2 SMA Negeri 2 Polewali telah mengikuti kegiatan praktikum di kelas $\mathrm{X}$, namun belum mengikuti praktikum di kelas XI. Kegiatan praktikum laju reaksi ini merupakan kegiatan praktikum pertama yang akan diadakan di kelas XI. Kedua, minat siswa dalam membaca masih terbilang kurang, sehingga dalam LKS ditambahkan beberapa ilustrasi gambar supaya siswa termotivasi untuk membacanya. Ketiga, siswa kurang mampu memahami bahasa yang tinggi, sehingga dalam LKS digunakan bahasa yang sederhana dan bersahabat serta masih banyak siswa yang memiliki kemampuan akademik yang kurang karena faktor kemalasan belajar. Keempat, dilihat dari karakteristik fisik siswa ditemukan semua siswa di kelas XI IPA $_{2}$ SMA Negeri 2 Polewali memiliki fisik yang normal.

c. Analisis tugas

Analisis tugas merupakan kegiatan sistematis dan terencana dalam rangka memperinci dan menentukan tugas utama yang dilaksanakan dalam proses pembelajaran. Selanjutnya dianalisis menjadi sub-sub tugas yang harus dikuasai siswa agar siswa dapat mencapai kompetensi minimal yang telah ditetapkan. Tugas yang telah dipilih ditentukan berdasarkan kurikulum KTSP yang berlaku di sekolah tempat penelitian dan standar kompetensi (SK) serta kompetensi dasar (KD) yang telah ditetapkan dalam silabus KTSP.

\section{d. Analisis konsep}

Analisis konsep adalah kegiatan identifikasi konsep atau materi yang akan diajarkan, mengumpulkan dan memilih materi yang relevan, dan menyusunnya kembali secara sistematis sesuai SK dan KD pada kurikulum KTSP. Konsep penting yang 
akan diajarkan melalui strategi pembelajaran inkuiri terbimbing pada materi laju reaksi secara garis besar antara lain kemolaran (molaritas), konsep laju reaksi, faktor-faktor yang mempengaruhi laju reaksi, teori tumbukan, orde reaksi dan persamaan laju reaksi, serta peranan katalis dalam makhluk hidup dan industri.

e. Perumusan tujuan pembelajaran

Perumusan tujuan pembelajaran merupakan transformasi dari analisis tugas dan analisis konsep menjadi suatu pernyataan agar terjadi perubahan perilaku yang diharapkan setelah belajar materi laju reaksi dengan menggunakan LKS dengan kata kerja operasional dan dapat diukur. Kompetensi dasar yang akan dicapai oleh siswa telah dijabarkan dalam beberapa indikator dan tujuan pembelajaran pada materi laju reaksi.

\section{Tahap II Perancangan}

Tujuan tahap ini adalah menyiapkan dan mendesain LKS berbasis inkuiri terbimbing, RPP serta beberapa media penunjang pembelajaran lainnya. Langkah-langkah yang perlu dilakukan pada tahap ini meliputi penyusunan tes acuan patokan, pemilihan media dan format serta perancangan awal untuk materi pembelajaran laju reaksi pada khusususnya.

a. Penyusunan tes acuan patokan

Menyusun tes acuan patokan berguna mengukur pencapaian siswa terhadap tujuan pembelajaran yang ditetapkan. Pencapaian ini diindikasikan dengan perubahan tingkah laku siswa baik dari segi kognitif, psikomotorik maupun afektif setelah kegiatan pembelajaran. Ranah kognitif diukur menggunakan tes tertulis berupa essay, penilaian psikomotorik berbentuk pengamatan performa dan penilaian afektif berbentuk pengamatan keaktifan. Pembuatan tes ini juga dapat dianggap sebagai proses operasionalisasi tujuan pembelajaran. Tes ini digunakan untuk mengetahui keefektifan LKS yang dikembangkan.

b. Pemilihan media

Pemilihan media perlu mempertimbangkan karakteristik materi dan karakteristik siswa serta harus sesuai dengan tujuan pembelajaran. LKS berbasis inkuiri terbimbing dipilih menjadi media pembelajaran utama yang akan digunakan dalam proses pembelajaran. Hal ini dikarenakan LKS berbasis inkuiri terbimbing adalah media yang dikembangkan. Adapun buku paket, alat dan bahan praktikum, serta papan tulis dijadikan sebagai media pembelajaran yang mendukung.

c. Pemilihan format

Format LKS yang disusun mencakup beberapa bagian, antara lain: (1) identitas LKS termasuk judul, mata pelajaran, semester, dan tempat; (2) petunjuk belajar; (3) kompetensi atau tujuan pembelajaran yang akan dicapai disesuaikan dengan KTSP; (4) indikator pencapaian berdasarkan KTSP; (5) informasi pendukung; (6) tugas-tugas; (7) langkah-langkah kerja; dan (8) penilaian.

d. Perancangan awal

Perancangan awal yang dilakukan pada penelitian ini adalah: (1) mendesain Rancana Pelaksanaan Pembelajaran (RPP) sesuai kebutuhan penelitian yang didasarkan pada KTSP; (2) mendesain Lembar Kerja Siswa (LKS) dimana LKS yang dibuat adalah LKS yang merupakan media/bahan ajar yang disusun berdasarkan strategi pembelajaran inkuiri terbimbing. LKS ini tidak seperti LKS pada umumnya, karena LKS ini dirancang untuk membuat siswa menemukan dan mengembangkan sendiri konsep dalam pembelajaran, berpikir kritis dan sistematis serta membangkitkan minat dan motivasi belajar; (3) desain pembelajaran pendukung, ada beberapa media penunjang yang digunakan untuk menunjang kegiatan pembelajaran siswa yang menggunakan LKS berbasis inkuiri terbimbing seperti; buku paket, papan tulis, serta alat dan bahan praktikum.

\section{Tahap III Pengembangan}

Tujuan utama dari tahap ini memperbaiki dan memodifikasi rancangan LKS dan perangkat lainnya. Walaupun telah diproduksi suatu prototipe pada perancangan awal, tetapi perlu dimodifikasi sebelum 
produk itu menjadi produk akhir yang memenuhi kriteria layak. Tahap ini terdiri atas 2 tahap yakni tahap penilaian ahli dan uji pengembangan.

a. Penilaian ahli

Penilaian ahli merupakan salah satu bentuk evaluasi formatif. Hasil evaluasi tersebut merupakan umpan balik atau tanggapan dari ahli. Berdasarkan umpan balik tersebut, LKS dapat direvisi dan dimodifikasi untuk meningkatkan kelayakannya.

Berdasarkan hasil validasi dari ketiga validator menunjukkan bahwa LKS berbasis inkuiri terbimbing yang dikembangkan termasuk dalam kategori "sangat valid" dengan nilai rata-rata total dari ketiga validator yaitu 3,32. Berdasarkan kriteria kevalidan pada Tabel 1, LKS berbasis inkuiri terbimbing telah memiliki derajat kevalidan dan layak untuk diujicobakan. Walaupun dikategorikan sangat valid, tetapi komentar dan saran tetap dipertimbangkan sebagai dasar perbaikan terhadap LKS.

Tabel 1. Kriteria Kevalidan LKS

\begin{tabular}{ll}
\hline Nilai Rata-Rata & Kriteria Kevalidan \\
\hline $3,26-4,00$ & Sangat valid \\
\hline $2,51-3,25$ & Valid \\
\hline $1,76-2,50$ & Kurang valid (direvisi) \\
\hline $1,00-1,75$ & Tidak valid (revisi total) \\
\hline
\end{tabular}

Sumber: Referensi [10]

b. Uji pengembangan

Uji pengembangan merupakan tahapan uji coba pembelajaran dengan menggunakan LKS berbasis inkuiri terbimbing terhadap sekelompok target. Dalam artian pada langkah ini dilakukan uji coba terbatas secara aktual terhadap sekelompok siswa pada situasi sebenarnya yaitu di dalam kelas dan/atau laboratorium. Selain itu tujuan dari tes ini juga untuk memperoleh umpan balik dari guru dan siswa berupa respon terhadap LKS yang dikembangkan. Melalui uji pengembangan ini akan diperoleh data keefektifan dan kepraktisan LKS. Uji pengembangan meliputi uji awal dan uji kuantitatif.
Uji awal merupakan suatu tahapan evaluasi formatif. Kegiatan ini dilakukan untuk memperoleh umpan balik dari guru berupa respon guru terhadap LKS yang dikembangkan. Dalam hal ini pengembang memberikan LKS kepada guru kemudian meminta umpan balik dari guru. Berdasarkan umpan balik ini LKS diperbaiki untuk meningkatkan kelayakannya. Pada uji awal diperoleh respon dari 3 guru kimia yang positif karena berada pada kategori "sangat baik".

Uji kuantitatif juga termasuk salah satu tahap evaluasi formatif. Kegiatan ini dilakukan untuk memperoleh umpan balik dari siswa sebagai subjek penelitian pada pengembangan media/bahan ajar ini dan pengguna LKS. Pengembang melakukan uji coba LKS secara aktual kepada sekelompok siswa pada proses pembelajaran di kelas dan/atau di laboratorium. Uji ini dikenal sebagai uji coba terbatas. Kemudian diminta umpan balik siswa terkait kepraktisan LKS yang digunakan selama pembelajaran berupa respon siswa, data uji keterbacaan dan keterlaksanaan serta data tes hasil belajar. Berdasarkan umpan balik ini LKS diperbaiki untuk meningkatkan kelayakannya.

Pada uji kuantitatif diperoleh (1) hasil tes acuan patokan untuk penilaian aspek kognitif, psikomotorik dan afektif siswa kelas XI IPA 2 . Hasil analisis deskriptif tes hasil belajar siswa setelah menggunakan LKS dapat dilihat pada tabel 2 .

Tabel 2. Hasil analisis Deskriptif Tes Hasil Belajar Siswa setelah Menggunakan LKS

\begin{tabular}{|l|c|}
\hline \multicolumn{1}{|c|}{ Variabel } & $\begin{array}{c}\text { Nilai } \\
\text { Statistik }\end{array}$ \\
\hline Subjek Penelitian & 32 \\
\hline Skor Ideal & 100 \\
\hline Rata-Rata & 81 \\
\hline Rentang Skor & 40 \\
\hline Skor Maksimum & 90 \\
\hline
\end{tabular}

Jurnal Nalar Pendidikan

Valume 6, Namar 1, Jan-Jun 2018 


\begin{tabular}{l|c|}
\hline Skor Minimum & 50 \\
\hline Jumlah Siswa yang Tuntas & 26 \\
\hline Jumlah Siswa yang Tidak Tuntas & 6 \\
\hline Hasil analisis deskriptif secara kuantitatif \\
terhadap aktivitas siswa pada aspek \\
psikomotorik dan afektif untuk mengetahui \\
keefektifan LKS yang dikembangkan dapat \\
dilihat pada Tabel 3 dan Tabel 4.
\end{tabular}

Tabel 3. Hasil Aktivitas Siswa untuk Aspek Psikomotorik

\begin{tabular}{ccccc}
\hline No & Nilai & Kategori & $\begin{array}{c}\text { Freku- } \\
\text { ensi }\end{array}$ & $\begin{array}{c}\text { Persentase } \\
(\%)\end{array}$ \\
\hline 1 & $85-100$ & $\begin{array}{c}\text { Sangat } \\
\text { Tinggi }\end{array}$ & 6 & 18,75 \\
2 & $65-84$ & Tinggi & 26 & 81,25 \\
3 & $55-64$ & Sedang & 0 & 0 \\
4 & $35-54$ & Rendah & 0 & 0 \\
5 & $0-34$ & Sangat & 0 & 0 \\
& & Rendah & & \\
\hline
\end{tabular}

Tabel 4. Hasil Aktivitas Siswa untuk Aspek Afektif

\begin{tabular}{|c|c|c|c|c|}
\hline No & $\begin{array}{l}\text { Perte- } \\
\text { muan }\end{array}$ & Nilai & $\begin{array}{c}\text { Persentase } \\
(\%)\end{array}$ & Kategori \\
\hline 1 & I & $\begin{array}{l}85- \\
100\end{array}$ & 92,75 & $\begin{array}{l}\text { Sangat } \\
\text { Tinggi }\end{array}$ \\
\hline 2 & II & $\begin{array}{c}65- \\
84\end{array}$ & 90,88 & $\begin{array}{l}\text { Sangat } \\
\text { Tinggi }\end{array}$ \\
\hline 3 & III & $\begin{array}{c}55- \\
64\end{array}$ & 91 & $\begin{array}{l}\text { Sangat } \\
\text { Tinggi }\end{array}$ \\
\hline 4 & IV & $\begin{array}{c}35- \\
54\end{array}$ & 87,38 & $\begin{array}{l}\text { Sangat } \\
\text { Tinggi }\end{array}$ \\
\hline 5 & V & $0-34$ & 92,75 & $\begin{array}{l}\text { Sangat } \\
\text { Tinggi }\end{array}$ \\
\hline Rat & $\begin{array}{r}\text { t-rata pe } \\
(\%)\end{array}$ & entase & 91 & $\begin{array}{l}\text { Sangat } \\
\text { Tinggi }\end{array}$ \\
\hline
\end{tabular}

(2) hasil respon siswa kelas XI IPA2terhadap kepraktisan LKS, hasil analisis deskriptif secara kuantitatif respon siswa terhadap LKS berbasis inkuiri terbimbingdapat dilihat pada Tabel 5.

Tabel 5. Hasil Respon Siswa

\begin{tabular}{ccccc}
\hline No & Nilai & Kategori & Frekuensi & $\begin{array}{c}\text { Persen- } \\
\text { tase } \\
(\boldsymbol{\%})\end{array}$ \\
\hline 1 & $85-100$ & $\begin{array}{c}\text { Sangat } \\
\text { Baik }\end{array}$ & 12 & 37,50 \\
\hline
\end{tabular}

\begin{tabular}{ccccc}
\hline 2 & $65-84$ & Baik & 19 & 59,38 \\
\hline 3 & $55-64$ & $\begin{array}{c}\text { Kurang } \\
\text { Baik }\end{array}$ & 1 & 3,12 \\
\hline 4 & $35-54$ & $\begin{array}{c}\text { Tidak } \\
\text { Baik }\end{array}$ & 0 & 0 \\
\hline 5 & $0-34$ & $\begin{array}{c}\text { Sangat } \\
\text { Tidak } \\
\text { Baik }\end{array}$ & 0 & 0 \\
\hline
\end{tabular}

(3) Hasil uji keterlaksanaan dan keterbacaan LKS berbasis inkuiri terbimbing terhadap kepraktisan LKS, uji keterbacaan dilakukan oleh 10 siswa kelas XI IPA 2 SMA Negeri 2 Polewali. Uji keterlaksanaan dilakukan oleh kedua observer untuk mengetahui sejauh mana pembelajaran dan praktikum dapat terlaksana. Pada uji keterlaksanaan diperoleh rata-rata total persentase sebesar 95\% yang dikategorikan "sangat baik", sementara ratarata total persentase yang diperoleh dari hasil uji keterbacaan sebesar $82,50 \%$.

Hasil penelitian pengembangan LKS berbasis inkuri terbimbing yang telah dilakukan selaras dengan hasil penelitian sebelumnya seperti yang dikemukakan di bagian pendahuluan bahwa pembelajaran dengan pendekatan inkuiri terbimbing dapat menarik minat serta motivasi belajar siswa sehingga mampu mengoptimalkan kemampuan siswa, yang akhirnya dapat meningkatkan hasil belajar siswa.

\section{KESIMPULAN}

Berdasarkan pembahasan hasil penelitian dan ujicoba terbatas terhadap siswa kelas XI $\mathrm{IPA}_{2}$ SMA Negeri 2 Polewali, dapat disimpulkan beberapa hal berikut:

1. LKS berbasis inkuiri terbimbing yang dihasilkan dan dikembangkan mengacu pada model pengembangan 4-D yang terdiri atas 4 tahap yaitu tahap pendefinisian (Define), tahap perancangan (Design) dan tahap pengembangan (Develop), sementara tahap penyebarluasan (Disseminate) tidak dilakukan, dimana kelayakan LKS yang dikembangkan dinilai berdasarkan kriteria valid, efektif dan praktis. 
2. Dari hasil validasi, uji awal, dan ujicoba terbatas diketahui bahwa LKS berbasis inkuiri terbimbing yang dikembangkan bersifat valid berdasarkan hasil penilaian para ahli/validator dan efektif berdasarkan hasil nilai kognitif, psikomotorik, dan afektif siswa serta praktis berdasarkan hasil uji keterlaksanaan, uji keterbacaan, respon guru dan respon siswa terhadap LKS.

\section{DAFTAR PUSTAKA}

[1]. Sanjaya, W. 2006. Strategi Pembelajaran Berorientasi Standar Proses Pendidikan. Bandung: Kencana Prenada Media Group.

[2]. Wahyuningsih, F., Saputro, S. Mulyani, S. 2014. Pengembangan LKS Berbasis Inkuiri Terbimbing pada Materi Pokok Hidrolisis Garam untuk SMA/MA. PAEDAGOGIA, Vol.17 (1): 94-103.

[3]. Haling, A. 2007. Belajar dan Pembelajaran. Makassar: Badan Penerbit Universitas Negeri Makassar.

[4]. Muhson, A. 2010. Pengembangan Media Pembelajaran Berbasis Teknologi Informasi. Jurnal Pendidikan Akuntansi Indonesia, Vol. VIII (2): 1-10.

[5]. Majid, A. 2013. Perencanaan Pembelajaran; Mengembangkan Standar Kompetensi Guru. Bandung: PT Remaja Rosdakarya.

[6]. Suyanti, R.D. 2010. Strategi Pembelajaran Kimia. Yogyakarta: Graha Ilmu.

[7]. Mappsoro. 2013. Strategi Pembelajaran. Makassar: Fakultas Ilmu Pendidikan UNM.

[8]. Wulandari, A.D., Kurnia., Sunarya, Y. 2013. Pembelajaran Praktikum Berbasis Inkuiri Terbimbing untuk Meningkatkan Keterampilan Berpikir Kritis Siswa SMA pada
Materi Laju Reaksi. Jurnal Riset dan Praktik Pendidikan Kimia, Vol.1 (1): $18-25$

[9]. Imaniarta, I., Sulistina, O., Yahmin. 2013. Pengembangan Buku Petunjuk Praktikum Kimia SMA Berbasis Inkuiri Terbimbing pada Materi Laju Reaksi dan Kesetimbangan Kimia. Skripsi. Universitas Negeri Malang.

[10]. Mawantia, T., Fajaroh, F., Afandy, D. 2013. Pengembangan Modul Berbasis Inkuiri Terbimbing (Guided Inquiry) pada Pokok Bahasan Reaksi Oksidasi Reduksi untuk Siswa SMK Kelas X. Skripsi. Universitas Negeri Malang.

[11]. Trianto. 2014. Model Pembelajaran Terpadu, Konsep, Strategi, dan Implementasinya dalam Kurikulum Tingkat Satuan Pendidikan (KTSP). Jakarta: Bumi Aksara.

[12]. Setyawardhani, V.M.M.N., Santoso, A., Marfu'ah, S. 2012. Pengembangan Modul Pembelajaran Kimia Materi Benzena dan Turunannya dengan Model Learning Cycle 5-E. JurnalOnline Universitas Negeri Malang, Vol.1 (1): 1-7. 